\title{
Atmospheric pollutants and hospital admissions due to pneumonia in children
}

\author{
Poluentes atmosféricos e internações por pneumonia em crianças \\ Contaminantes atmosféricos e internaciones por neumonía en niños
}

Juliana Negrisoli', Luiz Fernando C. Nascimento ${ }^{1}$

\section{ABSTRACT}

Objective: To analyze the relationship between exposure to air pollutants and hospitalizations due to pneumonia in children of Sorocaba, São Paulo, Brazil.

Methods: Time series ecological study, from 2007 to 2008. Daily data were obtained from the State Environmental Agency for Pollution Control for particulate matter, nitric oxide, nitrogen dioxide, ozone, besides air temperature and relative humidity. The data concerning pneumonia admissions were collected in the public health system of Sorocaba. Correlations between the variables of interest using Pearson cofficient were calculated. Models with lags from zero to five days after exposure to pollutants were performed to analyze the association between the exposure to environmental pollutants and hospital admissions. The analysis used the generalized linear model of Poisson regression, being significant $p<0.05$.

Results: There were 1,825 admissions for pneumonia, with a daily mean of $2.5 \pm 2.1$. There was a strong correlation between pollutants and hospital admissions, except for ozone. Regarding the Poisson regression analysis with the multi-pollutant model, only nitrogen dioxide was statistically significant in the same day (relative risk $-\mathrm{R} R=1.016$ ), as well as particulate matter with a lag of four days $(R R=1.009)$ after exposure to pollutants.

Conclusions: There was an acute effect of exposure to nitrogen dioxide and a later effect of exposure to particulate matter on children hospitalizations for pneumonia in Sorocaba.

Key-words: pneumonia; air pollutants; particulate matter; nitrogen dioxide; child health.

Instituição: Universidade de Taubaté (Unitau), Taubaté, SP, Brasil

1Unitau, Taubaté, SP, Brasil

\section{RESUMO}

Objetivo: Analisar a relação entre exposição aos poluentes atmosféricos e internações por pneumonia na infância, em Sorocaba, São Paulo.

Métodos: Estudo ecológico de séries temporais, no período de 2007 a 2008. Os dados diários das internações por pneumonia foram coletados na rede pública do município. Obtiveram-se também os dados dos seguintes poluentes, segundo a Companhia de Tecnologia de Saneamento Ambiental: material particulado, óxido nítrico, dióxido de nitrogênio e ozônio, além da temperatura e da umidade relativa do ar. As correlações entre as variáveis de interesse foram avaliadas pelo coeficiente de Pearson. Para analisar a associação entre a exposição aos poluentes ambientais e as internações hospitalares, aplicaram-se modelos com defasagens de zero a cinco dias após a exposição aos poluentes. A análise utilizou o modelo linear generalizado da regressão de Poisson e o nível de significância adotado foi $p<0,05$.

Resultados: Ocorreram 1.825 internações por pneumonia, com a média diária de 2,5 $\pm 2,1$. Observaram-se correlações fortes entre os poluentes e as internações, com exceção do ozônio. Quanto à regressão de Poisson, na análise com o modelo multipoluente, apenas o dióxido de nitrogênio apresentou significância estatística no mesmo dia (risco relativo $-\mathrm{RR}=1,016$ ), assim como o material particulado na defasagem de quatro dias ( $\mathrm{RR}=1,009)$ após a exposição aos poluentes.

Conclusões: Verificou-se efeito agudo da exposição ao dióxido de nitrogênio e efeito mais tardio da exposição ao material particulado sobre as internações por pneumonia em Sorocaba.

Palavras-chave: pneumonia; poluentes do ar; material particulado; dióxido de nitrogênio; saúde da criança.
Endereço para correspondência:

Luiz Fernando C. Nascimento

Rua Durval Rocha, 500 - Vila Paraíba

CEP 12515-710 - Guaratinguetá/SP

E-mail: luiz.nascimento@unitau.com.br 


\section{RESUMEN}

Objetivo: Analizar la relación entre la exposición a los contaminantes atmosféricos e internaciones por neumonía en la infancia, en Sorocaba, São Paulo (Brasil).

Métodos: Estudio ecológico en series temporales, en el periodo de 2007 a 2008. Los datos diarios de las internaciones por neumonía fueron recogidos en la red pública del municipio. Se obtuvieron además los datos de los siguientes contaminantes, según la Compañía de Tecnología de Saneamiento Ambiental: material particulado, óxido nítrico, dióxido de nitrógeno y ozono, además de la temperatura y humedad relativa del aire. Las correlaciones entre las variables de interés fueron evaluadas por el coeficiente de Pearson. Para analizar la asociación entre la exposición a los contaminantes ambientales y las internaciones hospitalarias, se aplicaron modelos con desfases de cero a cinco días después de la exposición a los contaminantes. El análisis utilizó el modelo lineal generalizado de la regresión de Poisson y el nivel de significancia adoptado fue $p<0,05$.

Resultados: Hubo 1.825 internaciones por neumonía, con un promedio diario de 2,5 $\pm 2,1$. Se observaron fuertes correlaciones entre los contaminantes y las internaciones, excepto por el ozono. Respecto a la regresión de Poisson, en el análisis con el modelo multicontaminante, solamente el dióxido de nitrógeno presentó significancia estadística en el mismo día (riesgo relativo $-\mathrm{R} R=1,016$ ), así como el material particulado en el desfase de cuatro días $(\mathrm{R}=1,009)$ después de la exposición a los contaminantes.

Conclusiones: Se verificó efecto agudo de la exposición al dióxido de nitrógeno y efecto más tardío a la exposición al material particulado sobre las internaciones por neumonía en Sorocaba.

Palabras clave: neumonía; contaminantes del aire; material particulado; dióxido de nitrógeno; salud del niño.

\section{Introduction}

Exposure to atmospheric pollutants represents an important risk factor for the exacerbation of respiratory diseases, generating high costs for the public health care network and significant respiratory morbidity ${ }^{(1)}$. In 2006, the financial costs of hospitalizations for pneumonia in children from zero to nine years old reached nearly $\mathrm{R} \$ 10$ million in the state of São Paulo and $\mathrm{R} \$ 690$ thousand in the city of Sorocaba ${ }^{(2)}$. Pneumonia, which occurs more frequently at extreme ages, represents the second leading cause of hospitalizations in these age groups ${ }^{(3)}$. Data from the city of São Paulo have been recently published, which show that, from 2000 to 2004, the age group from zero to five years old accounted for $80 \%$ of pediatric hospitalizations for respiratory diseases, and more than $85 \%$ of these hospitalizations were due to pneumonia ${ }^{(4-6)}$.

Pneumonia is a multifactorial disease. Air pollutants that reach the respiratory $\operatorname{tract}^{(6-8)}$ are currently responsible for its genesis, especially: particulate matter having an aerodynamic diameter equal to or less than $10 \mu \mathrm{m}\left(\mathrm{PM}_{10}\right)$, sulphur dioxide $\left(\mathrm{SO}_{2}\right)$, ozone $\left(\mathrm{O}_{3}\right)$, nitrogen dioxide $\left(\mathrm{NO}_{2}\right)$, and carbon monoxide $(\mathrm{CO})^{(7,8)}$.

The particulate matter produced by biomass burning, street dust and agricultural activity is formed by a carbon core where there are usually adsorbed ions, such as sulfates and nitrates, heavy metals, and biological materials, such as pollen, spores and bacteria ${ }^{(8)}$. $\mathrm{SO}_{2}$ irritates airways, leading to a decrease in pulmonary function ${ }^{(8)}$. $\mathrm{O}_{3}$ is a powerful oxidant that causes irritation of eyes and airways, with a decrease in pulmonary capacity ${ }^{(8)}$. The exposure to $\mathrm{NO}_{2}$ alters the mucociliary clearance mechanism, particle transport, and local immunity, favoring the onset of respiratory infections ${ }^{(8)}$.

Studies demonstrate that the effect of pollutant gases on the development of acute respiratory crises, represented by hospital admissions, has a gap (lag), which means that an individual exposed to pollution on a given day may be hospitalized on the same day or some days later ${ }^{(7,9)}$. Thus, this study estimated the association between exposure to atmospheric pollutants and hospitalizations for pneumonia in children below ten years old in Sorocaba.

\section{Method}

This is a time series ecological study conducted in Sorocaba, a city in the countryside of São Paulo state located $87 \mathrm{~km}$ far from the capital, with a population of approximately 600 thousand inhabitants, being considered a medium-sized city $^{(10)}$. Sorocaba has nearly 1,700 established factories, 15,300 trade points and 9,900 service providers ${ }^{(11)}$. Its geographical location is latitude $23^{\circ} \mathrm{S}$ and longitude $47^{\circ} \mathrm{W}^{(11)}$. It is crossed by two important roads with a heavy traffic of trucks and buses, which connect cities of São Paulo state with the state of Mato Grosso do Sul.

The daily levels of atmospheric pollutants, air temperature and humidity were obtained from the State Environmental Agency for Pollution Control (Companhia de Tecnologia de Saneamento Ambiental, Cetesb), which has a measuring station in Sorocaba. The data concerning pneumonia admissions were obtained from the Department of Information and Information Technology of the Brazilian Unified Health 
System (Departamento de Informações e Informática do Sistema Único de Saúde, Datasus) of the city, considering the period from January 1, 2007 to December 31, 2008. Daily means for the pollutants $\mathrm{PM}_{10}, \mathrm{NO}, \mathrm{NO}_{2}$ and the highest $\mathrm{O}_{3}$ value, measured in $\mu \mathrm{g} / \mathrm{m}^{3}$, were analyzed, as well as mean minimal air temperature and relative humidity. On Datasus database, we selected hospitalizations for pneumonia (CID10:J12-J18) of children from zero to ten years old. Pollutants were continuously assessed.

Models with lags from zero to five days after exposure to pollutants were performed to analyze the association between exposure to environmental pollutants and hospital admissions, using the generalized linear model of Poisson regression, because admissions are counting events.

Table 1 - Descriptive analysis of the study variables. Sorocaba, SP, 2007-2008

\begin{tabular}{llrrr}
\hline & Mean (SD) & Minimum & Maximum & Days $^{*}$ \\
\hline Hospitalizations & $2.5(2.1)$ & Zero & 14 & 716 \\
$\mathrm{PM}_{10}\left(\mu \mathrm{g} / \mathrm{m}^{3}\right)$ & $34.4(17.8)$ & 6.3 & 95.0 & 692 \\
$\mathrm{NO}\left(\mu \mathrm{g} / \mathrm{m}^{3}\right)$ & $12.4(16.3)$ & 0.1 & 115.3 & 675 \\
$\mathrm{NO}_{2}\left(\mu \mathrm{g} / \mathrm{m}^{3}\right)$ & $48.1(27.3)$ & 9.0 & 151.0 & 675 \\
$\mathrm{O}_{3}\left(\mu \mathrm{g} / \mathrm{m}^{3}\right)$ & $37.1(14.8)$ & 1.0 & 85.3 & 678 \\
Temperature $\left({ }^{\circ} \mathrm{C}\right)$ & $16.7(3.2)$ & 5.1 & 23.2 & 696 \\
Humidity $(\%)$ & $73.3(12.9)$ & 34.1 & 98.6 & 696 \\
\hline
\end{tabular}

*Days with recorded data; daily means; SD: standard deviation
The percentage increase in the risk of hospitalization (IRH) was estimated according to the expression: IRH $=\left[\exp ^{\left(\beta^{*} \Delta \mathrm{pol}\right)}-1\right] * 100$, where $\beta$ is the coefficient obtained from Poisson regression and $\Delta \mathrm{pol}$ is the variation, in $\mu \mathrm{g} / \mathrm{m}^{3}$, to be added in the concentration of the pollutant under analysis.

The risk of hospitalization was assessed using the Stata software, according to the lags from zero to five days, and adjusted for minimum temperature and mean air humidity by means of dependent variables (hospitalizations) and independent variables (pollutants and climatic variables). Descriptive analyses of all variables were performed, and correlations between the variables of interest were calculated using Pearson correlation.

The project was approved by the Research Ethics Committee (REC) of Universidade de Taubaté, under number 314/04.

\section{Results}

During the study period, there were 1,825 admissions of children from zero to ten years old due to pneumonia. Most hospitalizations occurred in dry periods and in the winter. The daily mean of admissions was $2.51 \pm 2.12$, ranging from zero to 14 admissions a day. Children's mean age was $3.8 \pm 2.6$ years, and median age was 3 years; in addition, $54 \%$ of the patients were male.

Table 2 - Pearson correlation between study variables. Sorocaba, SP, 2007-2008

\begin{tabular}{lccccccc}
\hline & Hospitalization & $\mathbf{P M}_{10}$ & $\mathbf{N O}$ & $\mathbf{N O}_{2}$ & $\mathbf{O}_{3}$ & Temperature & Humidity \\
\hline Hospitalization & 1.00 & - & - & - & - & - & - \\
$\mathrm{PM}_{10}$ & $0.19^{*}$ & 1.00 & - & - & - & - & - \\
$\mathrm{NO}$ & $0.22^{*}$ & $0.73^{*}$ & 1.00 & - & - & - & - \\
$\mathrm{NO}_{2}$ & $0.23^{*}$ & $0.88^{*}$ & $0.77^{*}$ & 1.00 & - & - & - \\
$\mathrm{O}_{3}$ & $-0.08^{* *}$ & 0.03 & $-0.35^{*}$ & $-0.16^{*}$ & 1.00 & - & - \\
Temperature & $-0.15^{*}$ & $-0.26^{*}$ & $-0.44^{*}$ & $-0.32^{*}$ & $0.22^{*}$ & 1.00 & - \\
Humidity & $-0.13^{*}$ & $-0.55^{*}$ & $-0.21^{*}$ & $-0.36^{*}$ & $-0.50^{*}$ & $0.19^{*}$ & 1.00 \\
\hline
\end{tabular}

*Significant correlation for $p<0.01$; ** significant correlation for $p<0.05$

Table 3 - Relative risks (RR) for hospitalizations for pneumonia with their respective 95\% confidence intervals (95\% $\mathrm{Cl})$ at lags from zero to five days after exposure to pollutants. Sorocaba, SP, 2007-2008

\begin{tabular}{lcccc}
\hline & $\mathbf{N O}\left(\boldsymbol{\mu g} / \mathbf{m}^{3}\right)$ & $\mathbf{N O}_{2}\left(\boldsymbol{\mu g} / \mathbf{m}^{3}\right)$ & $\mathbf{P M}_{10}\left(\boldsymbol{\mu g} / \mathbf{m}^{3}\right)$ & $\mathbf{O}_{3}\left(\boldsymbol{\mu g} / \mathbf{m}^{3}\right)$ \\
\cline { 2 - 5 } & $\mathbf{R R}(\mathbf{9 5} \% \mathrm{Cl})$ & $\mathbf{R R}(\mathbf{9 5} \% \mathbf{C l})$ & $\mathbf{R R}(\mathbf{9 5} \% \mathbf{C l})$ & $\mathbf{R R}(\mathbf{9 5} \% \mathbf{C l})$ \\
\hline Lag 0 & $1.002(0.996-1.007)$ & $1.016(1.007-1.025)^{*}$ & $0.991(0.984-0.998)$ & $0.995(0.990-1.000)$ \\
Lag 1 & $0.997(0.992-1.003)$ & $1.004(0.995-1.013)$ & $1.000(0.993-1.008)$ & $0.993(0.988-0.998)$ \\
Lag 2 & $1.002(0.997-1.008)$ & $0.994(0.985-1.004)$ & $1.005(0.998-1.012)$ & $0.993(0.998-0.998)$ \\
Lag 3 & $1.005(0.999-1.010)$ & $1.000(0.991-1.009)$ & $1.002(0.995-1.009)$ & $1.001(0.996-1.006)$ \\
Lag 4 & $0.998(0.993-1.004)$ & $0.999(0.990-1.008)$ & $1.009(1.002-1.016)^{*}$ & $0.998(0.993-1.003)$ \\
Lag 5 & $1.001(0.995-1.006)$ & $1.004(0.995-1.014)$ & $0.998(0.991-1.006)$ & $0.993(0.988-0.998)$ \\
\hline
\end{tabular}

${ }^{*} p<0.05$ 
The most frequent diagnosis was bacterial pneumonia (J15.8). There were 34 missing data for daily mean $\mathrm{PM}_{10}$ concentrations (4.6\% of the days analyzed), 51 (6.9\%) for $\mathrm{NO}$ concentrations, 51 (6.9\%) for $\mathrm{NO}_{2}$ concentrations, and $48(6.6 \%)$ for $\mathrm{O}_{3}$ concentrations. As for minimum temperature and mean humidity, there were 30 missing data $(4.1 \%$ of daily data). Table 1 shows the descriptive analysis of the study variables.

Table 2 presents the Pearson correlation coefficients of the study variables. There was a strong correlation between pollutants and hospital admissions.

Regarding the Poisson regression in the analysis with the multi-pollutant model adjusted for minimum temperature and mean humidity, only $\mathrm{NO}_{2}$ was statistically significant at lag zero, i.e., hospitalization occurred on the same day of exposure, and particulate matter at the lag of four days, i.e., hospitalization occurred four days after exposure. $\mathrm{O}_{3}$ was not found to be a risk factor. Table 3 displays the relative risks (RR) of hospitalizations for pneumonia regarding all pollutants under study with a 95\% confidence interval.

Graphs were developed for the daily pollutant concentrations and daily hospitalizations for pneumonia, as shown in Figures 1 and 2, respectively.

With a $10 \mu \mathrm{g} / \mathrm{m}^{3}$ increase in $\mathrm{NO}_{2}$ concentration, the risk of hospitalizations increased 16 percentage points and, as for $\mathrm{PM}_{10}$, the increase reached nine percentage points.

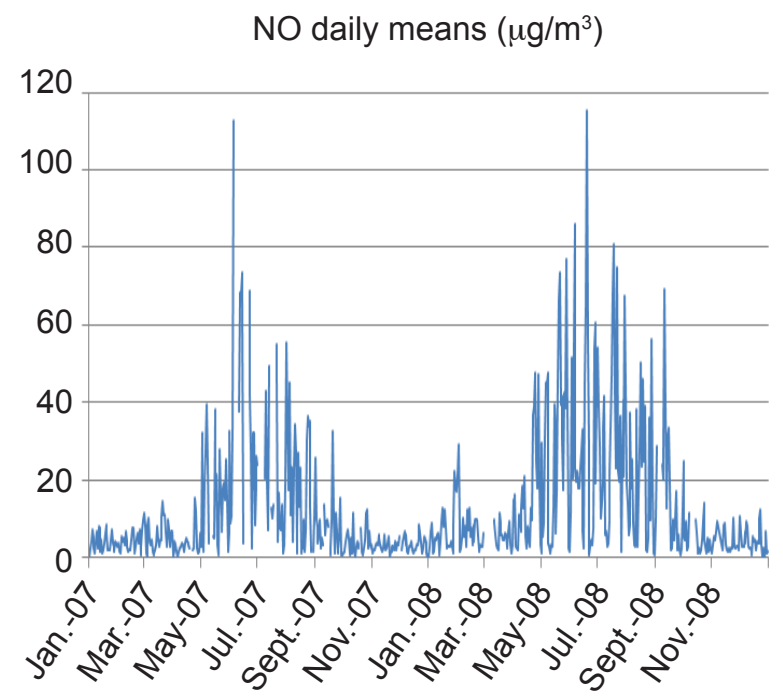

$\mathrm{PM}_{10}$ daily means $\left(\mu \mathrm{g} / \mathrm{m}^{3}\right)$
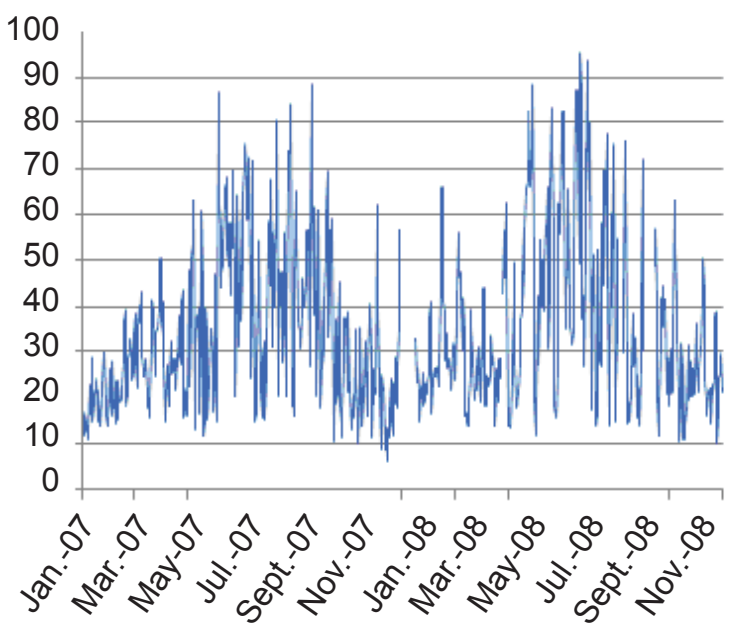

$\mathrm{NO}_{2}$ daily means $\left(\mu \mathrm{g} / \mathrm{m}^{3}\right)$

\section{$\mathrm{O}_{3}$ daily means $\left(\mu \mathrm{g} / \mathrm{m}^{3}\right)$}
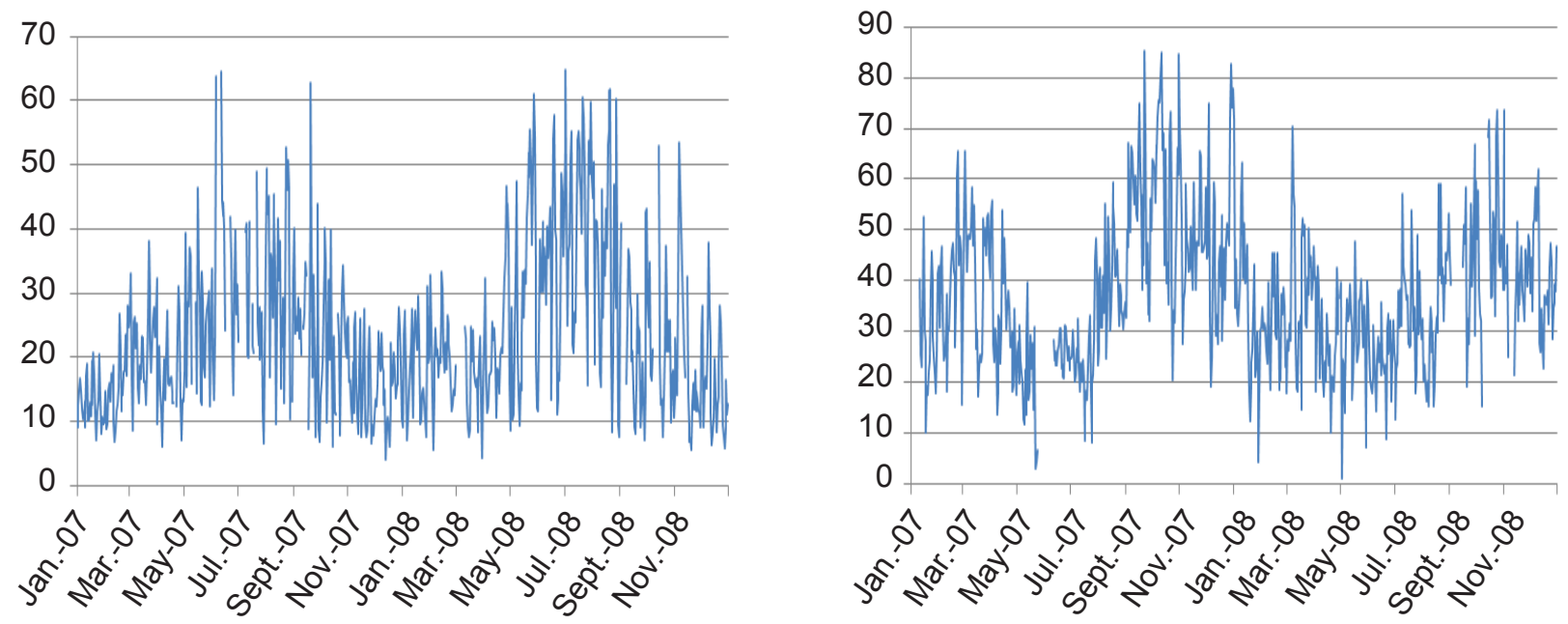

Figure 1 - Daily values of pollutant concentrations. Sorocaba, SP, 2007-2008 


\section{Discussion}

To date, this is the first study, conducted in Sorocaba, to analyze the effects of pollution on pediatric admissions due to pneumonia. Its results allowed us to reveal the acute effect of exposure to $\mathrm{NO}_{2}$ on hospitalizations, while the effect of exposure to particulate matter was a little late, four days after exposure, showing the important role of these pollutants on hospital admissions.

The concentrations of particulate matter found in Sorocaba were lower than those identified in the city of São Paulo ${ }^{(9)}, 54.5 \mu \mathrm{g} / \mathrm{m}^{3}$, and higher than those observed in São José dos Campos, Southeastern Brazil ${ }^{(12)}$, which reached $25.2 \mu \mathrm{g} / \mathrm{m}^{3}$, but they did not exceed the limit of $100 \mu \mathrm{g} / \mathrm{m}^{3}$, as recommended by the National Environmental Council (Conselho Nacional do Meio Ambiente, Conama).

In the case of the city of São Paulo, these values were associated with a higher relative risk of pediatric hospitalizations for pneumonia. In the study by Gouveia et a $l^{(9)}$, pneumonia in children was most frequent diagnosis among the causes of hospitalization for respiratory diseases reported in the study (more than 60\%) and there was an increase in the daily levels of pollutants and hospitalizations in the winter months. Exposure to particulate matter was also associated to pediatric admissions for pneumonia in São José dos $\mathrm{Campos}^{(7)}$, where exposure to concentrations of $40 \mu \mathrm{g} / \mathrm{m}^{3}$ was associated with a relative risk of $1.004-$ a value close to that found in Sorocaba ( $R R=1.009)$. In Cubatão ${ }^{(13)}$, a $56 \mu \mathrm{g} / \mathrm{m}^{3}$ increase in the concentration of this pollutant implied an increase of nearly $10 \%$ in the risk of pediatric hospitalization due to respiratory diseases, showing the consistency of the results obtained in Sorocaba.

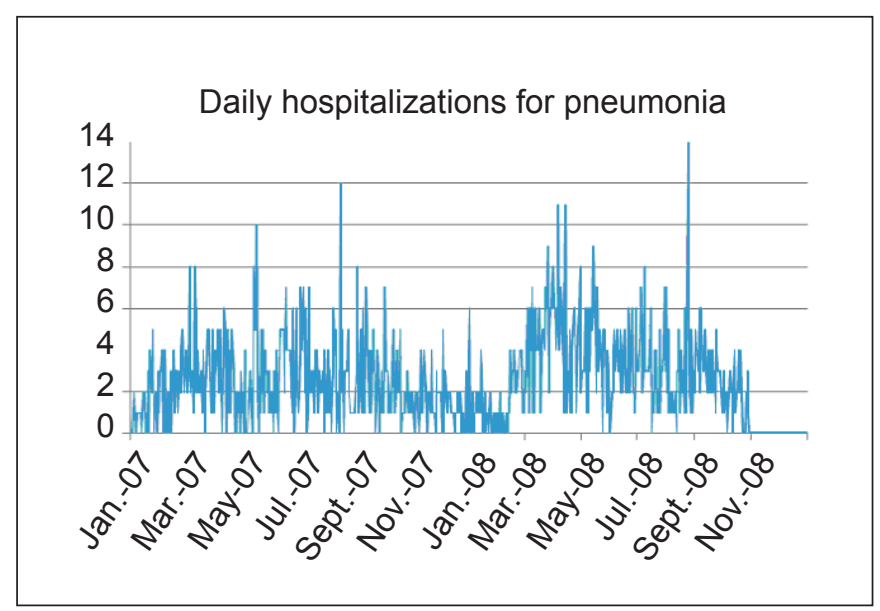

Figure 2 - Daily values of hospitalizations of children from zero to ten years old due to pneumonia. Sorocaba, SP, 2007-2008
With regard to $\mathrm{NO}_{2}$, the mean values found in this study $\left(48.06 \mu \mathrm{g} / \mathrm{m}^{3}\right)$, although exceeding the acceptable limit in 41 days $\left(100 \mu \mathrm{g} / \mathrm{m}^{3}\right)$, were below the values found in the city of São Paulo $\left(103 \mu \mathrm{g} / \mathrm{m}^{3}\right)^{(9)}$, but exposure to this pollutant was associated with admission for pneumonia in Sorocaba with similar risks. On the other hand, a study conducted in Cubatão, where there is a $\mathrm{NO}_{2}$ measuring station, found a mean concentration of nearly $27 \mu \mathrm{g} / \mathrm{m}^{3}$ and did not identify any association between exposure to $\mathrm{NO}_{2}$ and pneumonia in children ${ }^{(13)}$. A study conducted in Rio de Janeiro, Southeastern Brazil ${ }^{(14)}$, on emergency pediatric consultations in public health care units was not able to find an association between these consultations and exposure to $\mathrm{NO}_{2}$.

It was not possible to make further comparisons due to the lack of studies conducted in Brazil on exposure to $\mathrm{NO}_{2}$ and pediatric admissions for pneumonia.

The values found for $\mathrm{PM}_{10}$ and $\mathrm{NO}_{2}$ concentrations, which were lower than those observed in São Paulo and Rio de Janeiro, may be explained by the larger vehicle fleet and by the industrial park of these two capital cities, in comparison to the city of Sorocaba.

Several epidemiologic studies have shown the harmful effects of atmospheric pollutants on human health ${ }^{(1,7,9,12-14)}$, as well as their seasonal behavior, with higher concentrations in winter months, when air quality is compromised by the impaired pollutant dispersion due to the lack of rain and wind. In addition, there are also days with low air humidity and thermal inversions ${ }^{(7,8)}$. Investigations on asthma ${ }^{(12)}$ and pneumonia ${ }^{(7)}$ in Vale do Paraíba, Southeastern, and on respiratory diseases in São Paulo ${ }^{(9,15)}$ also found that pollutants show a seasonal behavior, like in this study.

It should be emphasized that $\mathrm{PM}_{10}$ and $\mathrm{NO}_{2}$ concentrations did not exceed the critical values acceptable by CONAMA; these values refer to pollutant concentrations that, when exceeded, may affect population's health ${ }^{(16)}$.

Like in the study by Gouveia $e t{ }^{(9)}$, we observed a predominance of admissions of male children, due to the lower diameter and higher tone of airways, with lower pulmonary flows during the first year of life, which are more evident in boys than in girls ${ }^{(15)}$.

A limitation of this study was the lack of measurements by Cetesb regarding $\mathrm{SO}_{2}$ and $\mathrm{CO}$ levels, both of them being powerful irritants of the respiratory tract. As for $\mathrm{SO}_{2}$, two studies conducted in São José de Campos ${ }^{(7,12)}$, a medium-sized city like Sorocaba, also with children from zero to ten years old, confirmed the harmful effect of this pollutant.

Another limitation may result from the exclusion of hospitalizations covered by health insurance plans and 
paying sources other than SUS. Additionally, there were cases of pneumonia in children treated in the outpatient clinic, i.e., that did not lead to hospitalization and were also not included in the study. Moreover, errors in disease coding may have contributed to an inaccurate accounting of cases. These limitations may collaborate to the underreporting of the occurrence of the disease. However, it should be emphasized that Datasus is an official source of the Ministry of Health and the data available on Datasus portal are used as material for epidemiologic studies. The reported hospitalizations refer to the portion of the population that relies on the public health service, i.e., the majority of the country's population.

Failures in the monitoring of pollutants during the study led to missing data, both in isolated days and in consecutive days. However, in time series ecological studies with daily data, the lack of some data did not interfere with final results, representing a possible confounding variable ${ }^{(9)}$. Individual exposures to gases were not considered and their concentrations were treated as homogenous throughout the city. Diagnostic errors or the double accounting of the same patient may have occurred. In addition, the greater demand to hospitals may be related to other risk factors, such as infections and allergies ${ }^{(9)}$. It is important to highlight that both ecologic studies and time series studies do not allow us to

\section{References}

1. Schwartz J. Air pollution and children's health. Pediatrics $2004 ; 113$ (Suppl 4):1037-43.

2. Brasil - Ministério da Saúde - DATASUS [homepage on the Internet]. Morbidade hospitalar do SUS - por local de residência - São Paulo [cited 2012 Aug 11]. Available from: http://tabnet.datasus.gov.br/cgi/tabcgi.exe?sih/cnv/mrsp.def

3. Marcilio I, Gouveia N. Quantifying the impact of air pollution on the urban population of Brasil. Cad Saude Publica 2007;23 (Suppl 4):S529-36.

4. Natali RM, Santos DS, Fonseca AM, Filomeno GC, Figueiredo AH, Terrivel $\mathrm{PM}$ et al. Hospital admissions due to respiratory diseases in children and adolescents of São Paulo city, 2000-2004. Rev Paul Pediatr 2011;29:584-90.

5. Macedo SE, Menezes AM, Albernaz E, Post P, Knorst M. Risk factors for acute respiratory disease hospitalization in children under one year of age. Rev Saude Publica 2007;41:351-8.

6. Nascimento LF, Marcitelli R, Agostinho FS, Gimenes CS. Hierarchical approach to determining risk factors for pneumonia in children. J Bras Pneumol 2004;30:445-51.

7. Nascimento LF, Pereira LA, Braga AL, Módolo MC, Carvalho JA Jr. Effects of air pollution on children's health in a city in Southeastern Brazil. Rev Saude Publica 2006;40:77-82.

8. Arbex MA, Santos UP, Martins LC, Saldiva PH, Pereira LA, Braga AL. Air pollution and the respiratory system. J Bras Pneumol 2012;38:643-55.

9. Gouveia N, de Freitas CU, Martins LC, Marcilio IO. Respiratory and cardiovascular hospitalizations associated with air pollution in the city of São Paulo, Brazil. Cad Saude Publica 2006;22:2669-77.

10. Brasil - Instituto Brasileiro de Geografia e Estatística [homepage on the Internet]. IBGE cidades@ [cited 2012 Aug 23]. Avaliable from: http://www.ibge.gov.br/ identify whether the child was admitted due to exposure to pollutants or whether the child exposed to pollutants was admitted. The design of this study is different from that of the study by Vieira et $a^{(17)}$, which individually measured 64 children and found that exposure to $\mathrm{NO}_{2}$ increased the risk of asthma and pneumonia.

The mechanisms through which environmental pollution interferes with human health are not fully understood yet. Particulate material seems to act via inflammatory mediators and oxidative stress, and responses seem to depend on the material adsorbed in particles, such as metals, organic carbon, ions (sulfates and nitrates) and other biogenic components ${ }^{(18)}$. The action of $\mathrm{NO}_{2}$, which is a free radical, has the potential to deplete tissue antioxidant defenses and thus cause local damage and inflammatory process ${ }^{(19)}$. In this context, epidemiologic studies focusing on this issue are essential, considering the proven respiratory morbidity and the negative impact of pollutants on people's quality of life, with hospitalization being only one of the many effects caused by air pollution ${ }^{(7,9)}$.

Thus, it was possible to find an association between exposure to the atmospheric pollutants $\mathrm{PM}_{10}$ and $\mathrm{NO}_{2}$ and hospital admissions for pneumonia in Sorocaba, which provides information for the development of policies to reduce risks to Public Health and especially to children's health.

11. São Paulo - Prefeitura Municipal de Sorocaba [homepage on the Internet] Sobre Sorocaba. Conheça melhor nossa cidade [cited 2012 Aug 23]. Avaliable from: http://www.sorocaba.com.br/sobre-sorocaba.html

12. Amâncio CT, Nascimento LF. Asthma and ambient pollutants: a time series study. Rev Assoc Med Bras 2012;58:302-7.

13. Jasinski R, Pereira LA, Braga AL. Air pollution and pediatric hospital admissions due to respiratory diseases in Cubatão, São Paulo state, Brazil, from 1997 to 2004. Cad Saude Publica 2011;27:2242-52.

14. Moura M, Junger WL, Mendonça GA, Leon AP. Air quality and acute respiratory disorders in children. Rev Saude Publica 2008;42:503-11.

15. Toyoshima MT, Ito GM, Gouveia N. Morbidade por doenças respiratórias em pacientes hospitalizados em São Paulo/SP. Rev Assoc Med Bras 2005;51:209-13.

16. Brasil - Ministério do Meio Ambiente [homepage on the Internet]. Resolução CONAMA n 003/1990 [cited 2012 Oct 13]. Avaliable from: http://www.mma. gov.br/port/conama/legipesq.cfm?tipo $=3 \&$ numero=03\&ano=1990\&texto=

17. Vieira SE, Stein RT, Ferraro AA, Pastro LD, Pedro SS, Lemos M et al. Urban air pollutants are significant risk factors for asthma and pneumonia in children: the influence of location on the measurement of pollutants. Arch Bronconeumol 2012;48:389-95.

18. Samet JM, Brauer M, Schlesinger R. Particulate matter. In: Word Health Organization, editor. Air quality guidelines: global update 2005. Copenhagen: WHO; 2006. p. 217-305.

19. Forastiere F, Peters A, Kelly FJ, Holgate ST. Nitrogen dioxide. In: Word Health Organization, editor. Air quality guidelines: global update 2005. Copenhagen: WHO; 2006. p. 331-94. 